\title{
The Union at War: South African Society, 1914-1953
}

\author{
Ian van der Waag •
}

The Union of South Africa was a twentieth century experiment in state formation. Forged in May 1910, the Union lasted until its submergence into the Republic of South Africa fifty-one years later. The period might conveniently be considered in four timespans. The first was the age of Botha and Smuts (191024) and their policy of reconciliation between English and Afrikaans South Africans, who had come recently through a violent war, the latter seeing their two republics subsumed first into the British Empire and then into the Union in 1910. The second time span, of similar length, was marked by the prime ministership of Hertzog (1924-39) and his South Africa First policy. Hertzog's fifteen years in power was arguably the quietest in terms of military activity. The return of Smuts to power (1939-48) marks the third period, while the advent of the first Nationalist governments under Malan and then Strydom and Verwoerd (1948-61) to the coming of the republic marks the fourth.

The Union Defence Force, as the armed forces of South Africa were called until 1957, engaged in several military conflicts during its lifespan. Several of these conflicts were, in the context of South African resources, small in scale and were not acknowledged as wars as such. Some conflicts involved South African territory, or territory mandated to South Africa under the League of Nations. Standing aside these there were three large wars fought principally far from the borders of the Union. The impact of these conflicts, whether internal conflicts or interstate wars, was at times severe for individuals and localised communities, but all had an effect on South African society as a whole. This collection of papers considers the effects of three, recognised "wars": the First World War (1914-18), the Second World War (1939-45), and the Korean War (1950-53).

The two world wars have been described as total wars, as unlimited conflicts involving the full mobilisation of the economic, social, political, and military resources of the belligerent states. Although this definition may oversimplify a complex, interconnected series of events and processes, the First and Second World Wars focussed attention in South Africa on social, political and economic institutions and in so doing, it has been argued, led to structural changes in South African society and raised hopes for a better, fairer post-war world. Saul Dubow, in a striking study on South African society, suggests that the events of the 1940s led to the imagination of 'at least three distinct worlds of possibilities ... each of which represented an incipient "new" South Africa and all of which looked to the post-war era as the dawn of a new order.' ${ }^{1}$ Only one, a republic based firmly on Afrikaner nationalism, was realised in the immediate post-war period. When the National Party came to power they were confronted immediately by the new realities of Cold War politics and, in 1950, with the outbreak of the Korean War. This war, fought far from South African shores and conducted by a less than eager nationalist government, was for South Africa on a much lesser scale.

Ian van der Waag, MA (Pretoria), PhD (Cape Town), is Professor of Military History and Head of the Department of Military History, Faculty of Military Sciences, Stellenbosch University. He is a guest editor for this special issue.

1 Saul Dubow, 'Introduction: South Africa's 1940s', in Saul Dubow and Alan Jeeves, eds., South Africa's 1940s; Worlds of Possibilities (Double Storey, Cape Town, 2005), p 2. 
There has been over the past two decades a burgeoning historiography on the formation of the Union Defence Force in July 1912 and the on the participation of the UDF in the two world wars and the smaller, internal conflicts. There is much less on Korea.

These three wars, the extent, nature and permanency of the political and socio-economic changes they brought, and the debates among historians regarding the relationship between warfare and societal change, forms the basis of the subject matter of this collection. While a serious, penetrating study of the impact of these war on South African society is still lacking, we hope to answer some questions and aide our understanding of some of the larger issues. 